\title{
OBITUARY : MISS ELIZABETH CARTWRIGHT
}

During her 38 years as Latin teacher at Rustenburg Girls' High School, Miss Elizabeth Cartwright gained the love and respect of the many generations of pupils who passed through her hands.

After matriculating at Muizenberg High School, where she acquired her lifelong love of Latin from an inspiring teacher, K.M. Hillhouse, she graduated B.A. B.Ed at UCT in 1949. After a few years of teaching in the Eastern Cape, first at Rocklands, Cradock, and then at Clarendon, East London, she was appointed to Rustenburg in July 1952. There she made a name for herself not only as a Latin teacher, but also as a hockey coach.

Miss Cartwright played a prominent part in the project lauched in 1978 by the Western Cape branch of the Classical Association to involve teachers in the preparation of commentaries on Latin texts which were prescribed for the JMB and CSC syllabus and for which, at that time, before the publication of Tria Saecula, all available commentaries were inadequate. The commentary on In Verrem, which Miss Cartwright did in association with others, was published in Akroterion.

After her retirement in March 1989 Miss Cartwright remained an active member of CASA. At the time of her death, in April 1993, she was studying Greek after attending a preliminary course at the UCT Summer School. She is survived by two sisters and a brother.

\section{Clodagh O'Dowd, Sans Souci High School}

